\title{
IMPLEMENTING COLLABORATIVE STRATEGY TO IMROVE READING COMPREHENSION THE ELEVENTH GRADERS OF SMK KERTHA WISATA MALANG
}

\author{
Chindy Hanggara Rosa Indah ${ }^{1}$, Yahmun ${ }^{2}$ \\ IKIP Budi Utomo Malang \\ Chindyhangara.ch@gmail.com \\ yahmunajha@gmail.com
}

\begin{abstract}
In this classroom action research, the researcher used the model of classroom action research developed by Kemmis and Mc Taggart (1999). There are four steps of teaching. Before doing those four steps, the researcher did reconnaissance step by observing the class situation and interviewing the class teacher and the students to know the problems. After knowing the problems, the researcher started to do the four steps of teaching they were planning, implementing, observing, and reflecting. The findings of this result showed that teaching reading comprehension using collaborative strategic reading improved the students` reading comprehension skill. In the first cycle the result was not satisfactory. The students were still passive in class because they did not understand about the method and many of them still found difficulty in understanding the texts. Their mean score of the first cycle was under the MMC. The criterion of success is when students give good response to this method, and also get the mean score that reach the MMC. After implementing the second cycle, the researcher found that the students were more enthusiastic because they knew about the topics of the texts and enjoyed comprehending the texts using CSR. They felt that the method was not boring. Besides that, the students mean score was 72.85 . The second cycle succeeded and proved that the students` mean score improved. It was above the MMC.
\end{abstract}

Key word: Class action research, collaborative strategy, reading, comprehension

CPendidikan Bahasa Inggris FPISH IKIP BU Malang

\section{Introduction}

Reading comprehension is the process of readers combining information from a text and their own prior knowledge to build meaning. Mc. Neil (1992:16) states that reading comprehension is acquiring information from the context and combining different elements into a new whole. It means that reading comprehension can be described as consisting of parting sentence, understanding sentence in discourse, building a discourse structure and then integrating this understanding with one already known.

In fact, reading is not as easy as people think. Reading is a complex process. There are some difficulties which are faced by people when they want to get information through reading. Reading a passage seems to be too difficult for them because of some conditions. The conditions here refer to the failure of understanding the words, the sentences, the sentences 'unity and organization, and the lack of interest or concentration. Those problems are often faced by the students in comprehending the text. Students may not be able to read themselves, fail to understand the relationship between the sentence and whole meaning of text. This case will be frustrating and de-motivating. Such attitudes often make unsuccessful experience in reading.

This is also supported by the result of researcher interview with the teacher before the research was done. The class teacher explained that he just used work in pair method, and it made students feel so bored and the result did not show a significant improvement. The students 
were still difficult to understand the text and the meaning of the text. Also, the teacher just used school book - LKS in their learning process. In addition, the teacher only targeted to finish the materials and exercises from the book. The teacher also explained that the students had low motivation in learning English especially in reading. They tended to be passive in class. Some students even did not have confidence in reading the text in front of their friends. The reason was that because they had limited knowledge of English vocabulary. Based on the fact above, the researcher concluded that the students problems appeared due to limited English vocabulary, low motivation in learning English and ineffective method of the English teacher

To strengthen the reason in this research, the researcher also joined the class to observe the condition of the student. From the observation it is found that some of the students found difficulties to do their task and discussed it with their friends. Some other students were busy opening their dictionaries to find the English words. At the end of the class, the teacher asked them to submit their work.

In conclusion, the researcher found many problems during the observation. First, the teacher taught in a monotonous way. It was not interesting and it made the students get bored. This could not help them to improve in reading. Second, the teacher was also not creative because he only applied activities based on the school book.

To overcome the problem of reading above the researcher applies the collaborative strategy to help the students improve the reading comprehension. As it is stated by Johnson (1987) CSR is a reading comprehension practice that combines two instructional elements: (a) modified reciprocal teaching and (b) cooperative learning. In reciprocal teaching, teachers and students take turns leading a dialogue concerning key features of text through summarizing, questioning, clarifying, and predicting. In addition, Klingner and Vaughn (1996) originally also designed CSR by combining modified reciprocal teaching with cooperative learning. Through a number of research trials, CSR has been refined and currently consists of four comprehension strategies that students apply before, during, and after reading in small cooperative groups. These reading strategies are: (a) preview (before reading), (b) click and clunk (during reading), (c) get the gist (during reading), and (d) wrap up (after reading).

In order to support the success of teaching reading comprehension using CSR, the selection material should also be considered. Klingner, Vaughn, Dimino, Schumm, \& Bryant, (2001) suggested in selecting reading materials for CSR, the following factors are recommended for consideration: 1 . Reading material.

(a) Reading materials at students 'instructional level, which generally refers to students being able to decode about $80 \%$ of the words correctly, (b) reading materials having themes and supporting details, and (c) reading materials consisting of several paragraphs. 2. Clunk cards. Each of the four clunk cards contains one fix-up strategy. Fix-up strategies included in the clunk cards are: (a) reread the sentence with the clunk and look for key ideas to help you figure out the word think about what makes sense, (b) reread the sentences before and after the clunk looking for clues, (c) look for a prefix or suffix in the word that might help, and (d) break the word apart and look for smaller words that you know. 1. Cue cards. Cue cards outline the procedures to be followed in a cooperative learning group. They remind students of each step 
of CSR for each role. Each role comes with a corresponding cue card that explains the steps to be followed to fulfill that role Learning log. CSR learning logs serve two roles: (a) written documentation of learning, assuring the individual accountability that facilitates cooperative learning, and (b) study guides for students.

\section{Research Method}

The research design applied in that research In research, the researcher used class action research (CAR). The CAR model used here was the model developed by Kemmis and McTaggart (1999: 32). According to the model, the implementation of the action research includes four steps. They are; identifying problems and planning the action, implementing the action and observing or monitoring the action, reflecting the result of the observation, and revising the plan for the following step.

Related to the research design above, this research used qualitative data obtained through observation and interview. However, this research also used quantitative data result in CAR because the researcher gave the test in the end of every cycle to know the students improvement. Those data were to support the analysis of final result of CAR since the test result can be one of the indications of whether the students comprehend the material

FIGURE 1

Cyclical Action Research model

\section{Planning Phase}

In this step, the researcher designed the teaching process in the classroom. The researcher prepared everything that she needed in the classroom, such as preparing the materials and the reading text. She also prepared the strategy and media used in CSR.

Table 2.1 Planning Schedule in the First Cycle

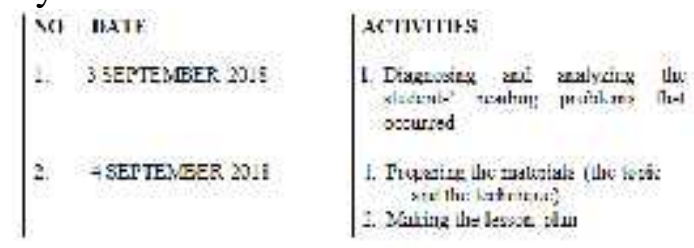

\section{Acting Phase}

In this step, the researcher conducted the action which was planned in the previous phase such as what the technique would be used, what materials would be chosen. In this step, the researcher applied collaborative strategic method to teach in the reading class. While teaching the students, the researcher also observed the students' response to get the qualitative data. The researcher also gave the students test in the last meeting to support the data.

\section{Observing Phase}

According to the Kemmis and Taggart (1999), the observation step was done while doing acting step. It means that the researcher also conducted the activity while doing observation. After acting, the researcher gave the test to 30 students.

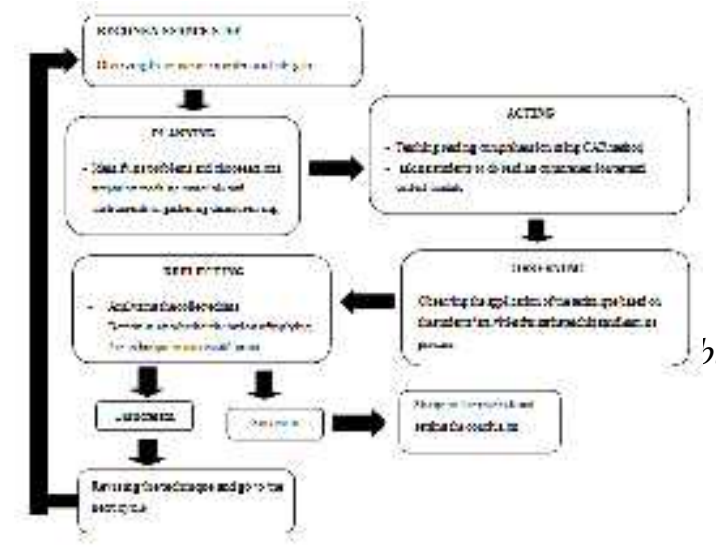

udiutomomalang.ac.id/index.php/journey 
In this phase, the researcher wrote all which happened in the class and also carried out observation toward implementation of the class using field note focusing on the students' reading comprehension aspects. When observing the researcher noticed and noted all of the activities in the classroom.

\section{Reflecting Phase}

The reflecting phase is to make evaluation from three previous steps. It was done based on the data that had been collected to hold evaluation for completing the action and observation result. After implementing the action, the researcher obtained the students' test result. In this research, the MMC was 70. If the first cycle was unsuccessful, it is necessary to conduct the second cycle. To determine the success criteria the researcher used qualitative data taken from the observation activity and quantitative data taken from the students test.

\section{Discussion}

This classroom action research was conducted in two cycles. Each cycle consisted of four steps; planning, acting, observing, and reflecting. The XI grade of SMK Kertha Wisata. Every cycle was conducted in 7 meetings included the test. In every last meeting, the researcher conducted the test to find out the improvement of students reading capability. The description of the findings and the interpretation of each cycle would be explained as follows.

\section{The Result of Observing in the First Cycle}

While implementing CAR, the researcher observed the teaching learning process and made field notes. It was about class situation, students` response to the method that the researcher used and the situation when they comprehended the reading texts.
Related to the students` response, only $40 \%$ of the students were active in the class and paid attention with the method that the teacher used. While $60 \%$ of them were still passive and gave less attention when the researcher delivered the lesson materials. They preferred to chat with their friends, and it was hard to manage them. When the researcher led the students to conclude the materials, only half of them answered enthusiastically while the rest of them still kept silent and looked confused.

Related to comprehend the reading text, $30 \%$ of the students were able to do it without many obstacles, while $70 \%$ students found difficulty to do it. They still found difficulty in finding the meaning even with clunk cards. They still got difficulty to find the idea of the text. These $70 \%$ students were still passive when they faced difficulty in understanding the method and often finished their work by copying the work of other friends from different groups.

\section{The Reflecting of the First Cycle}

In this phase, the researcher evaluated and revised the topic and the steps to get accurate data. To know the result of the first cycle, the researcher analyzed the data that the researcher got. In the process of interview, the researcher found that the class teacher already gave them some methods, but they did not improve the students reading comprehension capability. Most of the students found difficulty in understanding the text, and had limits vocabulary. They felt bored with the method that the class teacher gave. In implementing the technique, in cycle one, the researcher found that the students felt happy in the learning process because they got new method and teacher. Some of the students were active in following the method, but many of them still found difficulty in 
understanding the text. It could be shown from their learning $\log$ result. After implementing the technique, the researcher gave the test in the end of cycle one, and the researcher got the result score. The students' mean score was 64.64 , while the MMC was 70.00. It means that the first cycle was unsuccessful.

Related to the result above, the researcher needed to conduct the second cycle. Because the students' response was not satisfactory, they still found difficulty in understanding the method and reading text. Moreover, the students` mean score was still under the Minimum Mastery Criteria (MMC). In the second cycle, the researcher gave new materials and revised the activities to encourage the students to participate more in learning process.

\section{The Findings of the Second Cycle}

The second cycle was conducted based on the result of cycle one. When the result from observation showed that the quality was still low, it was needed to conduct the second cycle in order to improve the students capability in reading comprehension. The second cycle was conducted on October 12th 2018. The

Second cycle was implementing the collaborative strategic reading method in teaching reading comprehension. In the second cycle, the researcher still used CSR method. The difference between cycle one and cycle two was that the researcher revised the activities and topics. For cycle two, the researcher revised the steps and prepared different topic, the topics were Indonesian stories, ordered the students to bring their dictionaries, scheduled the time for the students to submit their assignment in every meeting, and the researcher also prepared the second test in the end of cycle two to collect the data.

\section{The Observing of the Second Cycle}

The observing in second cycle showed the better result than the previous cycle. In the second cycle, the students were more enthusiastic in comprehending the reading text by using CSR. The students participated more in the learning process especially in their groups during comprehending the text. They cooperated very well in this cycle. The students were also interested in answering the questions from the teacher. They did not face difficulties in finding the main ideas because most of them already understood about the text. In this cycle, the students daily exercise improved day to day because the researcher gave more detail correction and feedback. They were not reluctant to ask when they faced problems in comprehending the text. The finding result on the second cycle was better than the first cycle.

\section{The Reflecting of the Second Cycle}

The reflection of class action research (CAR) was carried out after getting the result of the second test. To know the result of the second cycle, the researcher analyzed the data that she obtained and found from the previous steps to know the difference between first cycle`s and the second cycle`s results.

According to the results of the evaluation done by the researcher and the English teacher, it could be assumed that collaborative strategic reading method was appropriate to be implemented to improve the students` reading comprehension skill. In this case, every action was planned as well as possible so that teaching goals could be accomplished. The students were enthusiastic. It was easy for them to understand the texts and the students were more confident to read the texts because CSR not only help them to 
understand the text well, but also trained them to be brave in reading the text loudly. The problems that the researcher faced in implementing the action were the students' weakness in grammar and limited knowledge of English vocabulary.

In the interview to the students in the last meeting after implementing the technique, the students stated that this technique made them more easily improve their reading comprehension skill, especially in understanding the reading texts. In addition, the technique was also interesting and fun. The students could work cooperatively. The researcher always had the students check the correct word spelling and the correct past forms. In the end, the class teacher said that CSR method was the alternative method to teach reading comprehension. It was able to improve the students capability in reading. It could be proved from the last test result.

The result of the second cycle test showed that the mean score of the students improved. The mean score of the students in the first cycle was 64.64. After CSR method was implemented the second cycle, the students` mean score was 72.85. It proved that the students' mean score improved after the second cycle was conducted. The students' mean score was above the Minimum Mastery Criterion (Kriteria Ketuntasan Minimal/KKM). The MMC was 70.00. Therefore, the researcher succeeded in conducting the classroom action research (CAR).

Related to the result of the interview above, it could be concluded that the researcher got good response in teaching reading by using CSR method.

\section{Conclusion}

Collaborative strategic reading (CSR) is an excellent teaching method for teaching students ' reading comprehension, building vocabulary and also working together cooperatively (Klingner, 1998). CSR is good method to improve students` reading skill with the students become the centre of learning process, because the way to do is that students work in groups on an arranged activity. This method consists of four comprehension strategies that students apply before, during and after reading in small cooperative groups. They are; preview (before reading), clink and clunk (during reading), get the gist (during reading), and wrap up (after reading). The used of CSR help students to improve their reading capability through some steps of CSR.

In this research the process of implementing CSR on the first cycle is not successful, because most of students were still passive and felt difficult in understanding the method. Their test mean score also still under the MMC. Here fore, the researcher conducted the second cycle and succeed with the better result. The students were more enthusiastic and interested in comprehending the text using CSR. The students also giving good response by not being reluctant to ask question when they faced problem in learning process. Besides that, the students' mean score achieved 72.85 which indicated that the researcher succeed in implementing CSR.

\section{References}

Arikunto, S. 2010. Prosedur Penelitian Suatu Pendekatan Praktik. Jakarta: Rineka Cipta.

Gunning, Thomas G. 1996. Creating Reading Instruction for All Children. Chapter 6, 192-236.

Johnson, D. W. \& Johnson, R. T. 1987. Research Shows the benefits of adult cooperation. Educational Leadership, 45, 3, 27-30. 
Kementrian Pendidikan dan Kebudayaan Republik Indonesia. 2015. Bahasa Inggris. Jakarta.

Kemmis, S. and McTaggert, R. 1999. The Action Research Planner. Geelong. Australia: Deakin University Press.

Kitao, Kathleen S. 1990. Textual Schemata and English Language Learning. Cross Currents, Issue 3, 147-155.

Klingner, J. K., Vaughn, S., \& Schumm, J. S. 1998. Collaborative strategic reading during social studies in heterogeneous fourthgrade classrooms. Elementary School Journal, 99(1), 3-2

Klingner, J. K. \& Vaughn, S. 1999. Promoting reading comprehension, content learning, and English acquisition through Collaborative Strategic Reading (CSR). The Reading Teacher, 52(7), 738-747.

Klingner, J. K. \& Vaughn, S. 1996. Reciprocal teaching of reading comprehension strategies for students with learning disabilities who use English as a second language. The Elementary School Journal, 96(3), 275-293.

McNeil, D. John. 1992. Reading comprehension: new directions for classroom practice. HarperCollins.p.16.

Palincsar, A.M., \& Brown, A.L. 1984. Reciprocal teaching of comprehension- fostering and comprehension-monitoring

activities. Cognition and Instruction, 1(2), 117-175.

Pelton, Robert P. 2010. Action Research for Teacher Candidates: Using Classroom Data to Enhance Instruction. R\&L Education. p.3.

Perkins, D.N. 1991. Educating for Insight. Educational Leadership. Issue 2, 4-9.
Vaughn, S., Klingner, J. K., \& Bryant, D. P. 2001. Collaborative strategic reading as a means to enhance peer-mediated instruction for reading comprehension and content area learning. Remedial and Special Education, 22(2),66-74. 